\title{
The Research of Latvian Language Competence of Secondary Education Institution Graduates for Career Development
}

\author{
DZenta Anspoka PhD \\ University of Latvia, University of Liepaja \\ zenta.anspoka@lu.lv
}

\begin{abstract}
The topicality of the research is related to the goal of education to help a pupil to become a proficient language user who has acquired not only the basic skills of the language, but also understanding of the role of the Latvian language as the state language in the integration of the society, formation of national identity and cultural-historical heritage preservation. The aim of the study is to analyse Latvian language competence of graduates of Latvian language of instruction, minority secondary education institutions and state gymnasiums of Kurzeme, Latgale and Riga for their readiness for further career development. The methodology of the research is the outcome of the career development and sociolinguistic and linguo-didactic theories, which are based on the cognitive constructivist approach. The results of the empirical research are obtained from 409 texts of judgments systematized in the balanced corpus of modern Latvian language texts within the framework of the National Research Programme "Latvian Language" (No VPP-IZM-2018/2-0002). Language competence of graduates from secondary education institutions is low. It is affected by the linguistic environment, attitude towards language as an economic and social value, its learning motivation and insufficiency in language didactics. The research outcomes outline several important aspects for the improvement of the Latvian language didactics.
\end{abstract}

Keywords: language competence, career development, critical thinking, language environment.

\section{Introduction}

Even though the modern processes of globalization and internationalization require good knowledge of English or other European and world languages, the issue of language competence of the particular state is not less important. In Latvia it is the Latvian language, which, in compliance with the Official Language Law, employees of state and local municipal institutions, courts and institutions belonging to the judicial system, as well as companies in which the majority of the capital belongs to the state or local government, must know and use to the extent necessary for professional and official duties - Article 6 of the Official Language Law (Official Language Law, 1999).

The topicality of the research results from the goal of education to help the pupil become a proficient language user who has acquired not only the basic skills of the language, i.e., listening, speaking, reading and writing skills, but also awareness of the role of the Latvian language as the state language in the integration of the society, the formation of national identity and cultural-historical heritage preservation, in their own emotional and intellectual experience enrichment (Regulations Regarding..., 2019).

Recently in the society, also including secondary school graduates there has been a tendency to be careless towards the cultural norms of the Latvia language and their application in communication. Even in the formal communication there often appears an unmotivated expressive conversation, slang, offensive, rude words, vulgarism, and it does not promote the development of language competence (Gavrilina, Špūle, 2018).

Results of the centralized examinations confirm that about $22 \%$ of the secondary school graduates are not able to write a text relevant to the topic, the structure of the text is not observed precisely, there are mistakes which result from incompetent word formation, lack of lexicostylistic skills. There are punctuation errors in a simple extended sentence in speech-to-text writing (end punctuation, connection of coordinated parts of the sentence, repeated words, non-restrictive apposition, separate participial phrases, exclamation words, particles, addresses and a group of address, insertions), in a compound sentence (syndetic or asyndetic connection, connection of sentence parts with the conjunction and), in a complex sentence (separation of subordinate clauses, collateral subordinate clauses, unnecessarily separated comparison, considering it as a subordinate clause), in sentence of direct speech, separating direct speech and the reporting verb, also including quotations in text (Skolēnu sasniegumu analīze..., 2007) 
The discussion of the focus group confirms that teachers also spot the biggest problems in pupils' inability to apply the terms of the Latvian language grammar and interpunction, inability of minority pupils to acquire in a qualitative way the content of the Latvian language curriculum. There are teachers who understand the pupil-centred approach, which envisages a more active involvement of pupils in grammar acquisition, such as a refusal form teaching language issues (Pêtījums..., 2020).

There is a correlation between language competence and pupil or student's academic achievement, their ability to self-realize, with issues related to personal development, since language is not only a means of communication, the language is also a means of experience accumulation, means of individual identity (Daszkiewicz, Wenzel, Kusiak-Pisowacka, 2018; Smékalová, Němejc, 2017).

The policy of Latvia education states that in a comprehensive secondary school, regardless of the student's ethnicity and place of residence, the Latvian language as the state language has to be acquired on such a level that its graduates could implement it not only for communication purposes, but also could perceive the language as a system of signs, could make reasoned judgments with the help of the Latvian language, would be able to self-realize in compliance with the situation and implement other important language functions.

The language is important for the secondary education graduate's career development, where career means a purposeful individual's activity in their development progress provision, including the process of profession acquisition (Pudule, 2013).

The language, in which the thought is materialized, is one of the means according to whose application we can judge what the person's level of thinking, level of knowledge, social environment, where they live, attitude towards oneself and the society in general is.

The aim of the study is to analyse Latvian language competence of graduates of the Latvian language of instruction, minority secondary education institutions and state gymnasiums of Kurzeme, Latgale and Riga for their readiness for further career development.

\section{Methodology}

The research question is - what is the level of language competence of graduates of secondary education institutions and what influences it?

The research methodology is the result of career development and sociolinguistic and linguo-didactic theories, which are based on the cognitive constructivism approach.

The research object is 409 texts of essays written by graduates of the Latvian language of instruction, minority secondary education institutions and state gymnasiums of Kurzeme, Latgale and Riga, which have been systematized in the balanced corpus of modern Latvian language texts. The empirical research has been carried out within the framework of the National Research Programme "Latvian Language" (No VPP-IZM-2018/2-0002).

The research method is the analysis of the content and linguistics of the essays systematized in the balanced text corpus in compliance with theoretically justified criteria. Applying the concordance analysis of language units, it is possible to judge not only about their frequency of use, but also about the most characteristic deviations from the norm. The obtained data have been rated and expressed as a percentage depending on the amount of the obtained data and interpreted to see the connections between the statements according to the issue raised in the research.

Regional dispersion, differences in secondary education institutions in terms of curriculum and social status have been observed to ensure higher data reliability, as well as the analysis of the content contained in the original texts in a broader context has been carried out, if the units found in the balanced modern Latvians language corpus reflects inaccurately the connection of the statements with the researched problem.

Descriptive statistical methods and graphical methods have been used in the text for the analysis of the data obtained in the study. 


\section{Results and discussion}

Nowadays an individual's career and its development are seen in a broader context. It is understood as human progress in social, professional and individual spheres throughout life, including also what happens outside working hours. Career development includes not only acquisition of a profession but also human personality development in general (Lemešonoka, 2017; Pudule, 2013; Jaunzeme, 2011). Career education focused on self-understanding, thinking about opportunities and making decisions (Urdzina-Merca, Dislere, 2018).

According to theories in the process of career development in different fields, such knowledge and skills of the Latvian language are required that a person could apply them in a competent way in communication, taking or giving advice, convincing of their knowledge and skills, dealing with information, synthetizing and analysing it, organizing and planning. The ability to assess the situation in a critical way, teamwork, ability to communicate with specialists from different areas, understanding of diversity and multiculturalism, ability to learn, ability to create new ideas (creativity), leadership skills of other people, project preparation skills, business correspondence and document preparation skills are not less important (Hughes, Acedo, 2016; Jaunzeme, 2011; Oroujlou, Vahedi, 2011; Lauze, 2011).

The ability to listen or read and perceive texts of other authors and the skill to create independently texts of different content, structure and language complexity are equally important.

The texts which a person creates in written speech are the basis of the structure of the language system, norms of speech and organization of the person's inner speech. Written speech in comparison with oral speech is more conscious and controlled. Analysing the texts of written speech, more information can be obtained on a person, their speech behaviour, life style, way of thinking, activities and values, attitude to themselves and the surrounding world, and also more objective assessment of their language competence (Anspoka, 2020; Vidnere, 2019; Alpar, 2013).

Broad linguistic knowledge, proficiency of the particular language lexis and grammar system, understanding of processes in language development and language policy and the skill to apply the knowledge of the language in practice are considered as language competence.

Language competence is a linguistically, psychologically and methodically organized system in which there is the unity of speech and language as a means. It is one of the individual's intellectual abilities characterized by conscious or intuitive knowledge of the language system to form grammatically and semantically correct expressions and implement a particular language function in a meaningful text. According to the socially linguistic approach, language competence is not an innate ability. It is formed when a person interacts with the social environment and acquires particular knowledge on the world and language system without separating one from the other. Language competence is closely related to sociocultural competence, as the grammar used in the text is a means of expressing the particular context (Vidnere, 2019; Daszkiewicz, Wenzel, Kusiak-Pisowacka, 2018; Mynbayeva, Shahanova, Zhanaikhan, 2015; Celce-Murcia, Olshtain, 2000).

The important criteria to judge an individual's ability to implement the purpose of communication in a written text are as follows:

- relevance of the content to the topic,

- the conditions of text composition are taken into account,

- unified whole of sentences, their sets or contextual connections,

- topic outlines and communicative assignment appropriate for the language style,

- adherence to the principle of completeness,

- adherence to the norms of language culture (orthoepy or orthography and punctuation) (Daszkiewicz, Wenzel, Kusiak-Pisowacka, 2018; Lauze, 2011).

The independently created 17-18-year-old youngsters' texts about such topics as the role of books in human life, challenges of the $21^{\text {st }}$ century and human mutual relationships enable us to see the writers' understanding of the chosen topic, also what their individual purpose of life, personal social-psychological maturity, understanding about social processes and the experience obtained at an educational institution are. 
Research results show that $96 \%$ of all graduates have the ability to relate the content of the text to the topic. Deviation from the topic is not a statistically significant indicator. At the same time only $57 \%$ of respondents adhere to the proportions between the parts of the text, connection of sentences, so that the text would appear as a wholeness, observe the principle of text completeness, and use paragraphs in appropriate places in the text. Reading the texts mentioned above, one has to admit that it is hard to follow the author's idea, as it is developed in a chaotic way without adhering to any basic principles of text logic.

Comparing the secondary education institution graduates' skills to reveal the depth of the content and observe the text structure, a higher quality can be noticed among the Latvian language of instruction and state gymnasium graduates of Riga and Kurzeme Region. In the work of graduates from Latgale secondary education institutions deficient or even wrong knowledge on such issues as Latvian or foreign literature, cultural events in Latvia and the world have been identified more often. In all regions graduates' understanding of what Christianity, cultural traditions, and types of art is careless; text genres, authors of art works or other work are mixed up. Graduates of secondary education institutions more often know the title of the work they have read, but not its author or mix them up with another one. Graduates reveal the particular knowledge either too generally, without justifying their opinion, or they reveal their subjective attitude towards the particular situations, and this is indicated by the following statements such as I think, that we- the youth understand more why such things happen, but it is only my point of view; I think everybody knows that music is necessary; my children's children will live in another century; I am sure and I know, that any of the films can make us think, appreciate what we have.

The expression of the content contained in the text is also closely linked to the choice of words and word forms, for their selection depends on what the speaker or writer pays attention to, and what beliefs are expressed. Research shows that $42 \%$ of all respondents also justify their statements. Graduates of Riga regional secondary schools and state gymnasiums are more confident about their opinion. The texts of these graduates contain the following statements in sentences such as I know that Aleksandrs Čaks had as interesting life as Kārlis Padegs; I know when purchasing the newest smart phone, I will confine myself in a cage, addiction cage. However, I do not resist these bars; technologies do miracles, but I know it seems wrong to elderly people, as they interfere into human lives. In $3 \%$ of respondents' expressions there dominate words always and only, verbs in the debitive mood, expressing categoricity, which has not been based on objective facts, but only in the writer's subjective opinion, for instance, it can be seen how technologies replace humans..., but we cannot escape form it, for we always make everything easier for ourselves; Bille was always dressed in good clothes, as Bille's father was a tailor; the book always has an amazing power which can influence human life; we always won't have enough time, we will always put some work on our shoulders, waste time on social networking sites, polishing our appearance, trying to cheat ourselves, thinking that it will help us; one seeks fame, another peace, another one exclusively material values; humanity will become lazier over time or in many thousands of years there will be only artificial intelligence; books will only be readable on computers and books will be plain pieces of paper with some patterns; only due to literature the whole world can understand metaphors, in which the concept of the heart is used; one always has to read good literature so that we would own an aesthetic taste; we have to learn from our mistakes in the past; in my opinion, to avoid lots of mistakes, we have to read a lot, as literature can change our life and make us happier. On average $2 \%$ of graduates use the reported speech and conditional mood or, either to stand apart from the responsibility for the statement or self-defend oneself in case somebody might not like the point of view, for instance, the modern youth are gifted, I would like to say, the future is in good hands; all people think they live and they have their duties; lots of people consider that classical books will disappear already in the nearest future; lots of elderly people believe that the youth do not treasure spiritual values, but rather material values; one could say that love, both from the psychological point of view and the chemical and biological, is so hard to be explained. Class 12 students of state gymnasiums and the Latvian language of instruction secondary schools use more foreign words, more complex syntactic constructions, and also expressions borrowed from mass media to express their opinions, especially if they talk about politics, such topical issues of the $21^{\text {st }}$ century such as development of technologies and society's multiculturalism. Both in secondary schools of the Latvian language of instruction and state gymnasiums there are children of minorities for whom the Latvia language is not their mother tongue. In the essays of these graduates the author's intentions can only be felt from a wider context due to their grammatical and stylistic errors. The issue of the language style and its compliance with the 
communicative intention is essential. The research outcomes confirm that only $29 \%$ of respondents apply accurately the means of language in compliance with the chosen language style. The expressive lexis is unduly used in texts, words are used with wrong lexical meaning, unmotivated colloquial words or expressions, for instance, books are a fantastic branch; one book took me over in its power; the book cures; a book as an emotion; theatres bring and give laughter; squander money; there is no need to feed the evil, churn cream, not get on one's nails, switch off mind (Figure 1).

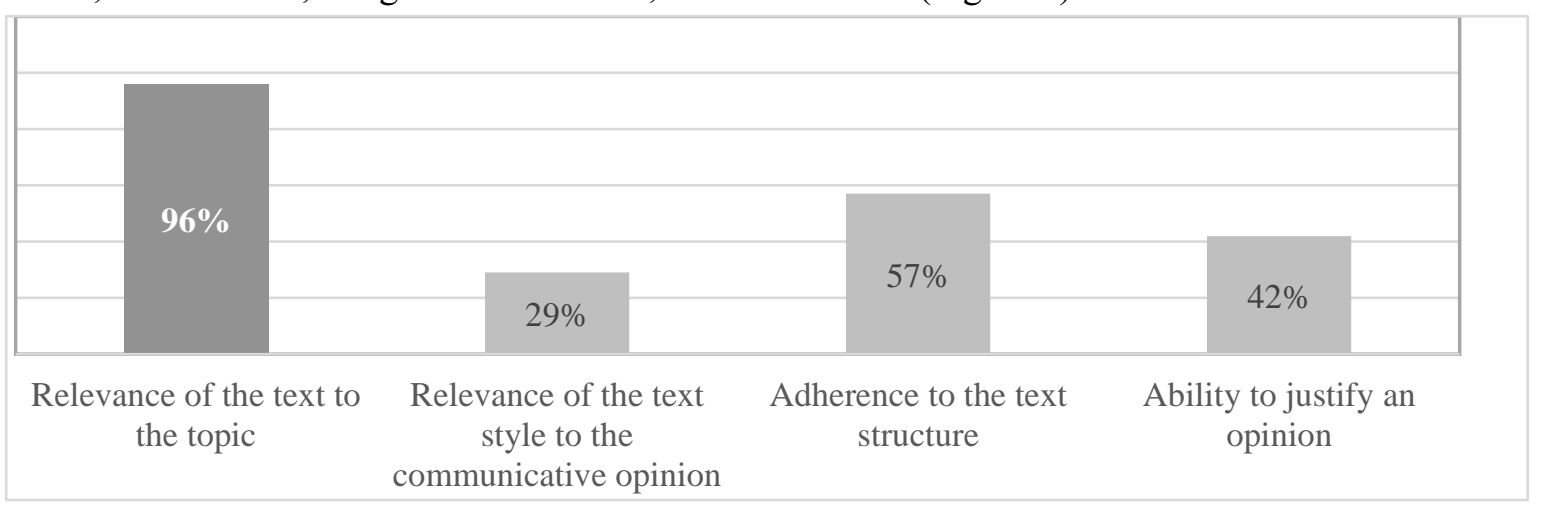

Figure 1. Text-formation skill.

In order a human being, having acquired secondary education, would be able to proceed with their education or integrate in the modern labour market, in which teamwork dominates, it is not enough that they are able to reproduce the knowledge of an issue. There are situations in which they have to justify their statements logically and correctly. It cannot be conceded that human statements contradict assumptions or axioms confirmed in a particular science. It is not less important to understand that the justification of an opinion is closely related to the sentence formation skill, in which a transition from one sentence to other happens, applying such syntactic constructions as because of...., as/since. (Ferretti, Graham, 2019). The research findings show that in the Latvian language acquisition process more attention should be paid to the acquisition of the argumentation skill, but also the work with lexis, especially foreign words, issues of functional style acquisition and speech genre requirements. To reduce too excessive categorization in youngsters' judgments, uncritical perception and assessment of the information found in mass media, intolerance of diversity, different opinions, more attention should be paid in the education process to critical thinking promotion, reasoned opinion expression based on facts, skills to assess information from the point of view of reliability of acquisition, tolerant attitude formation to different people in the society.

Studying secondary school students' skill to adhere to the orthography and punctuation norms, one has to admit that the mistakes are the same that have been noticed in the previous research studies (Skolennu sasniegumu analīze..., 2007; Gavriḷina, Špūle, 2018; Pētījums..., 2020; Anspoka, 2020). The level of Latvian language competence has decreased in the Latvian language of instruction schools and state gymnasiums. It can be explained due to the fact that in the education institutions mentioned above the number of students, for whom the Latvian language is the second language, has increased, as well as due to the need to compete with English and other foreign languages has increased for the Latvian language. In the texts of essays foreign words are used more often, but their lexical meaning and spelling are inaccurate or even wrong. Graduates most often use such foreign words spread in the social environment such as the Internet, media, innovations, creativity, stereotype, comfort, civilization, generation, filter, propaganda, emigrate, immigrate, uniqueness. It proves that the interdisciplinary link cooperation between teachers of different subjects has to be strengthened.

In the texts of graduates from minority secondary schools there are simpler sentence syntactic constructions, therefore the number of punctuation mistakes is smaller. However, mistakes of language interference, errors in the use of macron and palatalization marks in words, in use of word forms are more frequent. An overview of the most frequently made mistakes can be seen in Figure 2.

Findings of the research show that the quality of the Latvian language application is very diverse in different regions and for graduates of different type secondary education institutions. It is higher in Kurzeme and Riga regions, lower in Latgale. There are no statistically significant differences in terms 
of spelling of words and use of punctuation between graduates of the Latvian language of instruction and state gymnasiums, whereas there are significant differences in the quality of language use between minority and Latvian graduates. This suggests that the Latvian language is often just the language of instruction, but it is not the language of communication outside school hours, but also the transfer of the experience acquired in the mother tongue to the Latvian language, as the acquisition process of the second language, is not planned purposefully enough.

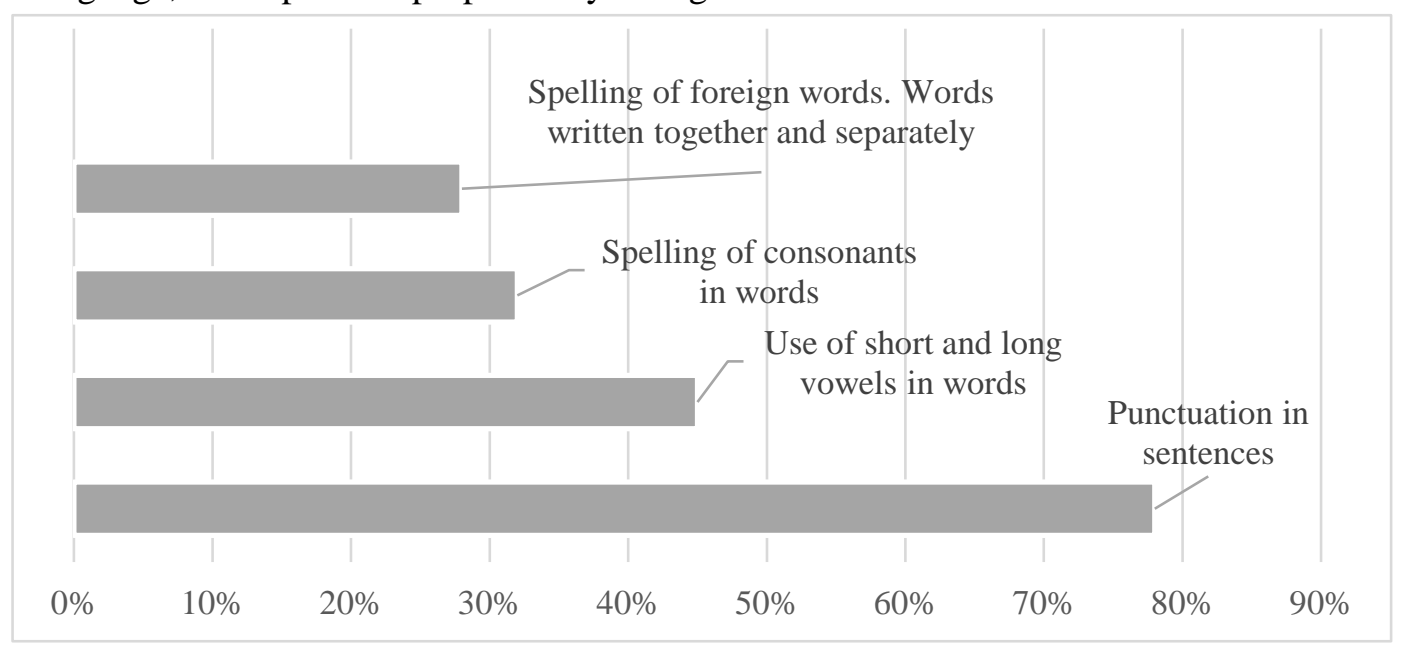

Figure 2. The most common language errors in terms of frequency.

The results of the research allow us to state that in the Latvian language didactics one should think more about a discourse-based language learning, in which the text first of all has the social context and not the linguistic form. Acquisition of grammar is not an end itself, but a means of the communicative purpose implementation.

In language learning, closely related to the acquisition of grammar regularity, knowledge of the world should also be improved. It is important for the student to see the relationship between discourse and the appearance of syntactic constructions, and the selection of words to reveal their knowledge and understanding about the particular issue (Celce-Murcia, Olshtain, 2000; Hughes, Acedo, 2016).

Development of language competence depends very much on the students' individual thinking abilities, their speed and depth, student and teacher's linguistic attitude. In the language competence acquisition process, it is important for every student to be the discoverer of language legitimacy in authoritative texts, self-created texts, and instructional texts which are used for the content acquisition of other subjects (Gavrilina, Špūle, 2018; Pêtījums..., 2020) and the teacher's professionality is the base of such work.

\section{Conclusions}

- An individual's career development requires Latvian language competence that is able to provide successful interpersonal communication, convince of their knowledge and skills, deal with information, able to learn, create new ideas, manage a team, and provide business correspondence.

- Language competence is characterized by conscious or intuitive knowledge of the language system to make grammatically and semantically correct statements and implement the particular language function in a meaningful text. According to the criteria, the language competence of graduates from secondary education institutions is on a low level.

- Graduates do not always follow the style appropriate for the communication intent, proportions between the text parts, the principle of text completeness, paragraphs, also progress of thought in compliance with basic conditions of the text logic.

- Punctuation errors predominate among orthography and punctuation errors, long and short vowels, application of consonants in words, spelling mistakes of foreign words and errors of the words to be written together or separately. 
- The level of language competence is influenced by the linguistic environment, attitude to the language as an economic and social value, as well as the didactics of the Latvian language.

- In the Latvian language didactics, language acquisition based on discourse should be highlighted, so that the grammar acquisition is not end in itself, but a means of the communicative intent implementation. More attention should also be paid to the pupil's critical thinking promotion, reasoned opinion expression based on facts, and ability to assess information from the credibility point of view.

- In order the graduate of a secondary education institution would be able to communicate in a multicultural environment, find a compromise or convince about their point of view, in the upbringing process it is essential to pay attention to the development of a tolerant attitude towards the different.

\section{Bibliography}

1. Alpar M. (2013). Importance of cultural elements in foreign language teaching. The Journal of Language and Linguistic Studies, 9(1), 95-106. Retrieved from http://www.jlls.org/vol9no1/vol9nolbook.pdf\#page=95

2. Anspoka Z. (2020). Youth Values: Analysis Outcomes of Latvia Secondary School Students' Essays. In Proceedings of the International Conference on Research in Education, Teaching and Learning, 3. Rome: Diamond Scientific Publishing, 1-12. Retrieved from https://www.dpublication.com/wp-content/uploads/2020/02/42-497.pdf

3. Celce-Murcia M., Olshtain E. (2000). Discourse and context in language teaching: A Guide for Language Teachers. Issues in Applied Linguistics 11(2), 277-279. Retrieved from https://escholarship.org/uc/item/4kx77286

4. Daszkiewicz M., Wenzel R., Kusiak-Pisowacka M. (2018). Education Role of language Skills. Gdansk: University of Gdansk.

5. Ferretti R.P., Graham S. (2019). Argumentative writing: theory, assessment, and instruction. Reading and Writing, 32, 1345-1357. doi: 10.1007/s11145-019-09950-x

6. Gavrilịna M., Špūle K. (2018). Latvijas skolēnu valodas (gramatiskās) kompetences analīze [Analysis of Latvia Pupils' language (grammar) Competence]. In A. Vulāne, E. Stikute (Eds.), Education for Science and Practice. Rīga: LU Akadēmiskais apgāds, 17-25. Retrieved from https://www.apgads.lu.lv/fileadmin/user_upload/lu_portal/apgads/PDF/Izglitiba-zinatnei0unpraksei/02_Gavrilina_Spule-IZP.pdf doi: 10.22364/izup (in Latvian)

7. Hughes C., Acedo C. (2016). Guiding Principles for Learning in the Twenty-first Century. Belley, France: UNESCO. Retrieved from https://repositorio.minedu.gob.pe/handle/MINEDU/5775

8. Jaunzeme I. (2011). Karjeras vadības un atbalsta sistēmas pilnveidošanas problēmas augstākajā izglìtība Latvijā [Development Problems of Career Management and Support System in Higher Education in Latvia]. (Doctoral Thesis, University of Latvia, Latvia, Riga). Retrieved from https://dspace.lu.lv/dspace/bitstream/handle/7/4591/16944-Inta_Jaunzeme_Dokt010022.pdf (in Latvian)

9. Lauze L. (2011). Ceḷā uz veiksmīgu saziṇu [On the Way to Successful Communication]. In G. Tramdaka (Ed.), Ar mūsdienu acīm uz klasiskām lietām: saturs un metodika. Rīga: Latviešu valodas ağentūra. 18-29. Retrieved from https://maciunmacies.valoda.lv/wpcontent/uploads/2020/03/09-Met_LAT_2.pdf (in Latvian)

10. Lemešonoka I. (2017). Skolēna karjeras vadības prasmju veidošanās vispārizglītojošās skolas pedagogiskajā procesā [Development of pupil's career management skills within the pedagogical process of general education schools]. (Doctoral Thesis, Riga Teacher Training and Educational Management Academy, Latvia, Riga). Retrieved from https://dspace.lu.lv/dspace/bitstream/handle/7/45285/prom_darbs_lemesonoka.pdf (in Latvian)

11. Mynbayeva A.P., Shahanova R.A., Zhanaikhan B. (2015). Methods of Forming Lingua-Cultural Competence in Postgraduate Education System. Mediterranean Journal of Social Sciences, 6(4), 172-175. doi: 10.5901/mjss.2015.v6n4s1p172

12. Official Language Law. (1999). Saeima. Retrieved from https://likumi.lv/ta/en/en/id/14740

13. Oroujlou N., Vahedi M. (2011). Motivation, attitude and language learning. Procedia - Social and Behavioral Sciences, 29, 994-1000. doi: 10.1016/j.sbspro.2011.11.333 
14. Pētījums “Attieksme pret latviešu valodu un tās mācību procesu” (2017-2020) [Research "Attitude to the Latvian Language and Its Learning Process (2017-2020)]. (2020). Retrieved from https://valoda.lv/wp-content/uploads/2020/04/petijums_info.pdf (in Latvian)

15. Pudule G. (2013). Karjeras izglītības vadības pilnveide vispārizglītojošās skolās Latvijā [Development of Career Education Management in Comprehensive Schools in Latvia].

(Doctoral Thesis, University of Latvia, Latvia, Riga). Retrieved from https://dspace.lu.lv/dspace/bitstream/handle/7/5221/39734-promocijas_darbs_Guna_Pudule.pdf (in Latvian)

16. Regulations Regarding the State General Secondary Education Standard and Model General Secondary Education Programmes. (2019). Cabinet Regulation No. 416. Riga: Cabinet of Ministers. Retrieved from https://likumi.lv/ta/en/en/id/309597

17. Skolēnu sasniegumu analīze tekstveidē latviešu valodas un literatūras centralizētajā eksāmenā: situācijas izpēte un ieteikumi [Analysis of Students' Achievements in Text-formation in the Latvian Language and Literature Centralized Examination: Situational Analysis and Suggestions]. (2007). Retrieved from https://www.visc.gov.lv/lv/media/454/download (in Latvian)

18. Smékalová L., Němejc K. (2017). Academic Performance of Students and Difficulty of University Education. In V. Dislere (Ed.), The Proceedings of the International Scientific Conference Rural Environment. Education. Personality (REEP), 11. Jelgava: LLU, 473-480. Retrieved from https://llufb.llu.lv/conference/REEP/2017/Latvia-Univ-Agricult-REEP-2017_proceedings-473-480.pdf

19. Urdzina-Merca I., Dislere V. (2018). Information and Communication Technology-Based Career Guidance Model for Young People. In V. Dislere (Ed.), The Proceedings of the International Scientific Conference Rural Environment. Education. Personality (REEP), 11. Jelgava: Latvia University of Life Sciences and Technologies, 406-415. doi: 10.22616/REEP.2018.050

20. Vidnere M. (2019). Valodas komunikatīvā kompetence starpetnisko attiecību attīstībā Latvijā [Communicative Competence of Language in inter-ethnic Relationship Development in Latvia]. Latvijas Zinātņu akadēmija vēstis, 73(2), 51-75. Retrieved from http://www.lasproceedings.lv/publikacija/valodas-komunikativa-kompetence-starpetniskoattiecibu-attistiba-latvija/ (in Latvian) 